\title{
The Relationship Between Personal and Organizational in Supply Chain Integration: Case study in Malaysia
}

\author{
Mahadi Hasan Miraz \\ School of technology Management and Logistics, PhD, University Utara Malaysia \\ Malaysia.mahadimiraz1@gmail.com \\ Mohamad Ghozali Hasan \\ School of technology Management and Logistics, Senior Lecturer, University Utara \\ Malaysia, Malaysia.ghozali@uum.edu.my
}

\section{Kamal Imran Sharif}

School of technology Management and Logistics, Senior Lecturer, University Utara Malaysia, Malaysia.kamalimran@uum.edu.my

\begin{abstract}
This study focuses on perusing how inter-personal relationship (IPRs) and inter-organizational relationships (IORs) interacts in the supply chain integration (SCI). Previous studies on supply chain integrations focuses more on inter-organizational relationships and ignoring inter-personal relationships. In this study an exploratory multiple case studies in Malaysia is used. We realize that in the early stage of supply chain integration, inter-personal relationships are identified as a precursor to building Inter-organizational relationships. During the operational stage, the two levels of relationships continuously interact with each other, until the end of the entire life-cycle of the dyad, inter-personal relationships helps in the emergence and growth pf IORs while the latter often uses these ties to negotiate for resource acquisition.
\end{abstract}

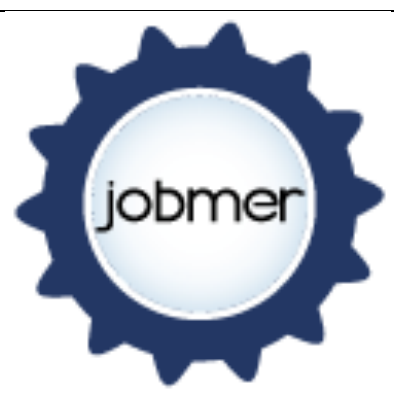

Journal of Business

Management and Economic Research

Vol.2, Issue.7, 2018 pp.

43-48

Doi: $10.29226 /$ TR1001.2018.48

Keywords: Case study, personal-organizational relationship,

Supply chain integration

\section{Introduction}

Supply chain integration is generally perceived to be a very important approach to intensify and boost both the effectiveness and efficiency of supply chain (Bowler, Castka \& Balzarova, 2015). Lots of previous study focused more on the organizational level relationship management and ignored the individual level relationship (Brown, Amundson \& Badurdeen, 2014). This study focuses on closing the knowledge gap on individual level relationship and to also investigate inter-personal relationship and interorganizational relationship interaction mechanisms during both formative and operational stages of the supply chain integration. According to Fahimnia, Sarkis and Eshragh (2015) inter-personal relationship has three facets: personal affection, personal 
communication and personal credibility (Banawi, \& Bilec, 2014). Based on the contentbased viewpoint, supply chain integration has to do mainly with information integration, strategic alliance, and process integration (Cabral, Grilo \& Cruz-Machado, 2012); Besseris \& Kremmydas, 2014). Due to the fact that both inter-personal relationship and inter-organizational relationship can be regarded as resources, we critically examined resource orchestration theory (ROT) in supply chain management through an assessment of dyadic relationship in supply chain integration at both individual and organizational levels (Aguado, Alvarez \& Domingo, 2013; Azevedo, Carvalho, Duarte \& Cruz-Machado, 2012). 7The two main questions that led the study are:

RQ1. How do IPRs and IORs interact in the formative stage of SCI?

RQ2. How do IPRs and IORs interact in the operational stage of SCI?

\section{Methodology}

The study makes use of an exploratory multiple case study approach in Malaysia. The data was carried out using semi-structured interviews of managers with varying supply chain responsibilities from both the suppliers and customers. While the qualitative data on the other hand, is triangulated with company archival information.

\section{Findings}

The study emphasized the crucial role of both inter-personal and inter-organizational relationships during supply chain integration (Bandehnezhad, Zailani \& Fernando, 2012); Bergmiller \& McCright, 2009). They are both valuable and incomparable resources, while the IOR is formal and exterior the IPR is informal and dependent. In the early stage of integration, inter-personal relationships come across as a prerequisite to building the inter-organizational relationships (Besseris, \& Kremmydas, 2014); (Campos, Campos, Vazquez-Brust \& Vazquez-Brust, 2016). However three important dimensions of IPRs work in relation: personal credibility acting as a facilitator that establishes inter-organizational confidence, personal affection acts as the gatekeeper, while personal communication accelerates the procedure (Elkington, 1998b). During the implementation stage, the two levels of relationships continuously relate with one another, with the possibility of strengthening and at times hindering the integration goal. All through the entire life-cycle of the dyad, IPRs helps in the establishment and growth of inter-organizational relationship while the latter often leverages these ties for resource acquisition.

\section{Discussion}

This study introduces orchestration theory by focusing and emphasizing on the interaction between inter-personal and inter-organizations relationships in supply chain management (Carvalho, Azevedo \& Cruz-Machado, 2010); (Carvalho, Duarte \& CruzMachado, 2011). The unclear scheme of the three inter-personal dimensions need to be organized and groomed to strengthen their effects on inter-organizational relationships (Castka \& Balzarova, 2008); (Cherrafi, Elfezazi, Chiarini, Mokhlis \& Benhida, 2016). In the same vein, the inter-personal and inter-organizational relationships of the supply chain integration process need to be organized in terms of breadth, depth and stage of life-cycle (Dües, Tan \& Lim, 2013). 


\subsection{Managerial implications}

The study provides senior decision makers in the top level management with more authentication of the important role of inter-personal relationships across a realm of managerial levels when working with business associate (Chiarini, 2014); (Duarte \& Cruz-Machado, 2013b). Furthermore, the study ascertains when personnel with special skills and competence should be used during the different stages of developing and preserving inter-organizational ties (Dhingra, Kress \& Upreti, 2014); (Duarte \& CruzMachado, 2013a).

\subsection{Sustainable Performance}

The circular economy concept has started to be recognized as of great potential to help organizations achieve a breakthrough in environmental sustainability performance. It has quickly become an influential driving force behind sustainability, both in literature and practice (Genovese, Acquaye, Figueroa \& Koh, 2017). The circular economy concept aims to redesign global production and consumption systems (Hobson, 2016). Through eco-industrial initiatives, where wastes produced at one point in a value chain are turned into inputs at another point (Mathews \& Tan, 2011). These results in the creation of self-sustaining production systems, where most used products, scraps, residual materials, and other waste materials are collected, conditioned, and reused or recycled to improve material efficiency and profitability Preston, 2012). The concept puts sustainability and closed-loop thinking at the heart of business models and industrial organizations (Winkler, 2011)

\section{Conclusion}

The use of the integration for the dimensions of complexity might reflect a growing interest in the construct from various supply chain perspectives. However, the same variety potentially limits a more coherent understanding of personal and organizational supply chain integration. Complexity is not merely the opposite of simplicity nor did a synonym for complicacy, where everything deemed complicate can be addressed as complexity.

\section{References}

Genovese, A., Acquaye, A. A., Figueroa, A., \& Koh, S. L. (2017). Sustainable supply chain management and the transition towards a circular economy: Evidence and some applications. Omega, 66, 344-357.

Hobson, K. (2016). Closing the loop or squaring the circle? Locating generative spaces for the circular economy. Progress in Human Geography, 40(1), 88-104.

Mathews, J. A., \& Tan, H. (2011). Progress toward a circular economy in China. Journal of industrial ecology, 15(3), 435-457.

Preston, F. (2012). A global redesign? Shaping the circular economy. Energy, Environment and Resource

Governance, 2, 1-20. 
Winkler, H. (2011). Closed-loop production systems-A sustainable supply chain approach. CIRP Journal of Manufacturing Science and Technology, 4(3), 243246.

Aguado, S., Alvarez, R., \& Domingo, R. (2013). Model of efficient and sustainable improvements in a lean production system through processes of environmental innovation. Journal of Cleaner Production, 47, 141-148.

Azevedo, S. G., Carvalho, H., Duarte, S., \& Cruz-Machado, V. (2012). Influence of green and lean upstreamsupply chain management practices on business sustainability. IEEE Transactions on engineeringmanagement, 59(4), 753-765.

Banawi, A., \& Bilec, M. M. (2014). A framework to improve construction processes: Integrating Lean, Green andSix Sigma. International Journal of Construction Management, 14(1), 45-55.

Bandehnezhad, M., Zailani, S., \& Fernando, Y. (2012). An empirical study on the contribution of lean practices to environmental performance of the manufacturing firms in northern region of Malaysia. InternationalJournal of Value Chain Management, 6(2), 144-168.

Bergmiller, G. G., \& McCright, P. R. (2009). Lean manufacturers' transcendence to green manufacturing. Paper presented at the Proceedings of the 2009 industrial engineering research conference.

Besseris, G. J., \& Kremmydas, A. T. (2014). Concurrent multi-response optimization of austenitic stainless steel surface roughness driven by embedded lean and green indicators. Journal of Cleaner Production, 85,293-305.

Bowler, K.,Castka, P., \& Balzarova. (2015). Understanding Firms' Approaches to Voluntary Certification: Evidence from Multiple Case Studies in FSC Certification

Brown, A., Amundson, J., \& Badurdeen, F. (2014). Sustainable value stream mapping (Sus-VSM) in different manufacturing system configurations: application case studies. Journal of Cleaner Production, 85, 164-179.

Fahimnia, B., Sarkis, J., \& Eshragh, A. (2015). A tradeoff model for green supply chain planning: A leannessversus- greenness analysis. Omega, 54, 173-190.

Cabral, I., Grilo, A., \& Cruz-Machado, V. (2012). A decision-making model for lean, agile, resilient and green supply chain management. International Journal of Production Research, 50(17), 4830-4845.

Campos, L. M., Campos, L. M., Vazquez-Brust, D. A., \& Vazquez-Brust, D. A. (2016). Lean and green synergies in supply chain management. Supply Chain Management: An International Journal, 21(5), 627-641.

Carvalho, H., Azevedo, S. G., \& Cruz-Machado, V. (2010). Supply chain performance management: lean and green paradigms. International Journal of Business Performance and Supply Chain Modelling, 2(3-4), 304-333.

Carvalho, H., Duarte, S., \& Cruz Machado, V. (2011). Lean, agile, resilient and green: divergencies and synergies. International Journal of Lean Six Sigma, 2(2), 151179. 
Castka, P., \& Balzarova, M. A. (2008). ISO 26000 and supply chains - On the diffusion of the social responsibility standard. International Journal of Production Economics, 111(2), 274.

Cherrafi, A., Elfezazi, S., Chiarini, A., Mokhlis, A., \& Benhida, K. (2016). The integration of lean manufacturing, Six Sigma and sustainability: A literature review and future research directions for developing a specific model. Journal of Cleaner Production, 139, 828-846.

Chiarini, A. (2014). Sustainable manufacturing-greening processes using specific Lean Production tools: an empirical observation from European motorcycle component manufacturers. Journal of Cleaner Production, 85, 226-233.

Dhingra, R., Kress, R., \& Upreti, G. (2014). Does lean mean green? Journal of Cleaner Production, 85, 1-7.

Duarte, S., \& Cruz-Machado, V. (2013a). Lean and green supply chain initiatives: a case study. Paper presented at the IIE Annual Conference. Proceedings.

Duarte, S., \& Cruz-Machado, V. (2013b). Modelling lean and green: a review from business models. International Journal of Lean Six Sigma, 4(3), 228-250.

Dües, C. M., Tan, K. H., \& Lim, M. (2013). Green as the new Lean: how to use Lean practices as a catalyst to greening your supply chain. Journal of Cleaner Production, 40, 93-100.

Elkington, J. (1998b). Partnerships from cannibals with forks: The triple bottom line of 21 st century business. Environmental Quality Management, 8(1), 37-51. 